\title{
ANTIDEPRESSANT-INDUCED HYPONATREMIA
}

Letícia H. Cury, Fábio T. Kitadai, Claudia M. B. Helou

Hyponatremia is the electrolytic disorder most commonly observed among general hospitalized populations, being found in $2 \%$ of hospitalized patients..$^{1-3} \mathrm{~A}$ form of hyponatremia is the syndrome of inappropriate antidiuretic hormone secretion (SIADH). This syndrome consists of faulty urine dilution in the presence of plasma hyposmolality. It is an osmoregulatory disorder that has many causes, including medications. ${ }^{4}$

Selective Serotonin Reuptake Inhibitors (SSRIs) can cause hyponatremia due to SIADH, particularly among the elderly.

\section{CASE REPORT}

The present case is a 77-year-old male patient with clinical history of systemic blood hypertension, diabetes mellitus, vascular dementia syndrome and depression. He was an outpatient on $67.5 \mathrm{mg} /$ day Captopril ${ }^{\circledR}, 35 \mathrm{U} /$ day $\mathrm{NPH}$ insulin and $50 \mathrm{mg} /$ day sertraline hydrochloride (prescribed six months prior to hospitalization).

The patient was admitted to the hospital with lack of appetite, somnolence and fever. He was diagnosed with infection of the urinary tract and therapy with antibiotics was instituted.

Basal evaluations showed the following values: 146 $\mathrm{mEq} / \mathrm{l}$ serum sodium, $5.4 \mathrm{mEq} / \mathrm{l}$ serum potassium, $1.5 \mathrm{mg} /$ $\mathrm{dl}$ creatinine and $58 \mathrm{mg} / \mathrm{dl}$ urea.

Twenty days later, concomitantly with the progressive increase of sertraline to $100 \mathrm{mg} / \mathrm{day}$ the serum sodium level had decreased to $125 \mathrm{mEq} / \mathrm{l}$, while the potassium level increased to $5.8 \mathrm{mEq} / \mathrm{l}$. One possibility was the onset of adrenal insufficiency and corticoid treatment was started, while measures were taken against hyperpotassemia. Although the potassium level returned to normal, hyponatremia persisted.

The cortisol level was normal $(12.5 \mu \mathrm{g} / \mathrm{dl})$, as well as the thyroid function (TSH 2.8 and FT4 1.17).

The fact that the patient still had hyponatremia in the

Hospital do Servidor Público Municipal - São Paulo/SP, Brazil E-mail:leticiacury@hotmail.com presence of low serum osmolality $(270 \mathrm{mosm} / \mathrm{kg}$ ) pointed to SIADH.

A treatment was instituted that included hydric restriction, 3\% $\mathrm{NaCl}$ infusion and Furosemide ${ }^{\circledR}$.

After 48 hours the sodium level had already increased and four days later the sodium level had reached $130 \mathrm{mEq} /$ 1 , although it started decreasing again even though maintenance treatment was kept.

The exclusion diagnosis was drug-related SIADH secondary to the use of SSRIs.

Many non-pharmacological causes of SIADH were excluded based on normal thoracic radiograph and cranial tomography. The patient was also subjected to abdominal CT, rectosigmoidoscopy and high digestive endoscopy, none of which showed any changes, tumor markers were negative.

Sertraline was suspended and serum sodium level increased progressively until its normal value. At the time of hospital discharge, it had reached $136 \mathrm{mEq} / 1 ; 15$ and 30 days after the hospital discharge the serum sodium level still was within the limits of the normal range (135 and $138 \mathrm{mEq} / \mathrm{l}$, respectively).

\section{DISCUSSION}

In spite of being the most usual ethiologic factor for hyponatremia in hospitalized elderly patients ${ }^{2}$, as well as the most common cause of normovolemic hyponatremia (accounting for $14-40 \%$ of cases of hyponatremia), SIADH is normally diagnosed by exclusion. ${ }^{5}$

Criteria for a SIADH diagnosis include serum sodium below $135 \mathrm{mEq} / \mathrm{l}$, osmolality below $280 \mathrm{mosm} / \mathrm{l}$, volume expansion (without clinical hypervolemia or edema), hypertonicity of urine as compared to blood, and absence of dehydration. It is worth noticing that a correct diagnosis requires thyroid, adrenal and renal functions to be normal. ${ }^{2,5}$

Many are the causes of SIADH and they may be divided into four categories: neoplastic, central nervous system disorders, lung diseases and use of medications. ${ }^{5}$

The incidence of hyponatremia among elderly patients treated with antidepressants of the SSRI class has been reported with increasing frequency. ${ }^{6-12}$

The prevalence of hyponatremia in the elderly due to 
the use of SSRIs varies between 0.5 and $25 \%$, with an incidence of $4.7 / 1000$ treated patients per year. ${ }^{11,12}$

Although half of the patients are asymptomatic, the mortality rate among elderly patients with hyponatremia may reach $25 \% .^{13}$

Hyponatremia generally develops during the first month of therapy ( 3 to 120 days) and is reversible between 2 and 28 days after the suspension of the SSRI. ${ }^{10}$

In our patient, hyponatremia occurred 20 days after the dose of sertraline was increased, and the serum sodium levels returned to the normal range 21 days after drug withdrawal.

Risk factors include old age, low body mass index, concomitant use of diuretics, and female sex..$^{10,11,12,14}$ This patient, is male, but exhibited all the other risk factors for developing SIADH.

Euvolemic hyponatremia combined with reduced serum osmolality and the absence of hypothyroidism and adrenal insufficiency pointed to SIADH.

Extensive investigation for malignancy, and lung, liver, heart and kidney disease was performed, and no other nonpharmacological cause of SIADH was evidenced.

The diagnosis was confirmed by the response to drug withdrawal.

Since hyponatremia is a not-so-rare side effect among elderly patients treated with antidepressants of the SSRI class and is associated to mortality increase, monitoring the serum sodium level is recommended while this class of drugs is being used.

\section{REFERENCES}

1. Kumar S, Berl T. Sodium. Lancet.1998;352:220-8.

2. Adrogue HJ, Madias NE. Hyponatremia. N Engl J Med. 2000;342:15819.

3. Elisaf MS, Milionis HJ, Siamopoulos KC. Electrolyte abnormalities in the elderly patients admitted to a general medical ward. Geriatr Nephrol Urol. 1991;7:73-9.

4. Belton K, Thomas SHL. Drug induced syndrome of inappropriate antidiuretic hormone secretion.Postgrad Med J. 2000;76:318.

5. Oliveira S, Vilar L, Cavalcanti N. Manuseio da síndrome da secreção inapropriada da ADH. Endocrinologia clínica. 2a ed. Rio de Janeiro: Medsi; 2001. p.125-34.

6. Spigest $\mathrm{O}$, Hedenmalm K. Hyponatremia in relation to treatment with antidepressants. Health Organization database for spontaneous reporting of adverse drug reactions. Pharmacotherapy. 1997;17:348-52.

7. Woo MH, Smythe MA. Association of SIADH with selective serotonin reuptake inhibitors. Ann Pharmacather. 1997;31:348-52.

8. Cohen BJ, Mahelsky M, AdlerL. More cases of SIADH with fluoxetine. Am J Psychiatry. 1990;147:948-9.
9. Pillans PI, Coulter DM. Fluoxetine and hyponatremia:a potencial hazard in the elderly. NZ Med J. 1994;107:85-6.

10. Liu BA, Mittman N, Knowes SR, Shear NH. Hyponatremia and the syndrome of inappropriate secretion of antidiuretic hormone associated with the use of selective serotonin reuptake inhibitors: a review of spontaneous reports. Can Med Assoc J. 1996;155: 519-27.

11. Bouman WP, Pinner G, Johnson H. Incidence of selective serotonin reuptake inhibitor induced hyponatraemia due to the syndrome of inappropriate antidiuretic hormone secretion in the elderly. Int J Geriat Psychiatry. 1998;13:12-5.

12. Wilkinson TJ, Begg EJ, WinterAC, Sainsbury R. Incidence and risk factors for hyponatremia Following treatment with fluoxetine or paroxetine in elderly people. Br J Clin Pharmacol. 1999; 47:211-7.

13. Ayus JC, Arrief AI. Chronic hyponatremic encephalopathy in postmenopausal women. JAMA. 1999;281:2299-304.

14. Chan TYK. Drug-induced syndrome of inappropriate antidiuretic hormone secretion. Drugs \& Aging. 1997;11:27-44. 